\title{
Exchange Rate and Stock Price Nexus: Evidence from Ghana
}

\author{
Peter Arhenful, Richard Fosu, \& Mathew Owusu-Mensah \\ Accounting and Finance Department, Accra Technical University, Accra, Ghana \\ parhenful@atu.edu.gh; rfosu@atu.edu.gh; mowusu-mensah@atu.edu.gh
}

\begin{abstract}
This study aimed at investigating the link between the Ghanaian exchange rate and stock prices from July 2007 to December 2019, to establish whether appreciation in exchange rate causes stock price increases or otherwise. The Ghana Stock Exchange's (GSE) All-Share Index; served as a proxy for stock prices, while nominal monthly exchange rates for the Ghana Cedi in terms of the US Dollar were utilized as a proxy exchange rate. The Pearson's Product Moment Correlation test was employed to evaluate the link between the two variables, and the Augmented Dickey-Fuller (ADF) test was employed to determine the data's stationarity qualities. The series were all non-stationary since they had unit roots; however, stationarity was attained at the first difference. The results of the regression and correlation analysis conducted revealed that the two macroeconomic variables are negatively connected in the Ghanaian context. In view of the negative association between the exchange rate and stock prices in Ghana, the study advises policymakers to be cautious when implementing exchange rate measures.
\end{abstract}

Keywords: Exchange Rate, Stock Prices, Correlation.

\section{Introduction}

Instability in the exchange rate has been found to have a pervasive effect on the prices of all commodities and services in the economy, including stock prices. In recent years, both economics and finance literature have expressed concern regarding the link between exchange rates and stock prices. The stock prices of companies listed on the GSE show their success and overall financial health. As a result, while diversifying and hedging their portfolios, both domestic and international investors profit from understanding the nexus between stock prices and exchange rates (Adeyeye et al., 2017). However, there has been little research, into the exchange rates and stock prices nexus in Ghana. The trade effect reveals the effect of exchange rates on stock prices (Geske \& Roll, 1983). Exchange rate variations influence stock market investors' rates of return both domestically and internationally. When the demand for export commodities is elastic, a drop in the value of the domestic currency leads to a rise in the volume of exports. As a result, cash flow and liquidity in domestic companies improve, causing stock prices to increase. A flow-oriented model is a popular approach for determining the connection between exchange rates and stock prices. Stock price movements, according to this model, influence aggregate demand via the wealth effect, liquidity effect, and currency rates. An increase in inflation, as well as an increase in the exchange rate, would cause stock prices to decline because an increase in interest rates reduces the present value of cash flows (Bunheng et al., 2020).

The results of empirical analysis on exchange rates and stock prices nexus have been inconclusive and contradictory. On the one hand, studies by Bahmani \& Saha (2016), Caporale et al. (2015); Ülkü \& Demirci (2012) found a positive link between stock prices and exchange rates, whereas studies by Caporale et al. (2015), Chkili \& Nguyen (2014), and Wong (2017) found a negative relationship. Wickremasinghe (2011) also contends that stock prices and currency rates are linked in both the short and long term. Alagidede et al. (2011) and Amarasinghe \& Dharmaratne (2014), on the other hand, discovered no statistically significant link between the two variables. As a result, the goal of this research is to see if there is a link between stock prices and the Ghanaian exchange rate. The research is motivated by the following research question: Is there a link between Ghana's exchange rate and stock prices? This hypothesis was examined in light of the study question: $\mathrm{H}_{0}$ : In Ghana, exchange rate and stock prices have no link. Specifically, $\mathrm{HO}:=0 . \mathrm{H}_{1}$ : In Ghana, the exchange rate and stock prices have a positive relationship. Specifically, H1: $>0$. The following is how the research paper is structured: The introduction is presented in section 1.0, the relevant literature on the exchange rate and stock price connection is reviewed in section 2.0, and the methodology of the paper is outlined in section 3.0 while Section 4.0 presents the findings and discusses them. Section 5.0 however, concludes the study. 


\section{Related Literature}

In economics and finance literature, the causal linkage between exchange rates and stock prices are well documented. According to the commodity market hypothesis, a change in exchange rate affects multinational enterprises' competitiveness and, as a result, their earnings, which brings about changes in stock prices (Granger et al., 2000; Agrawal et al., 2010, Alagidede et al., 2011). When the value of a local currency falls, export prices fall as well, which generally leads to an increase in demand for foreign items and, thus, increases the value of exports? Volatility in exchange rates can affect both international corporations and local businesses with limited overseas operations. Exchange rate fluctuations have a great effect on input and output pricing, as well as demand for products and services. Owing to exchange rate swings, stock values are influenced, resulting in equity movements and flight. During the Asian financial crunch, Granger et al. (2000) used time-series data to conduct a unit root and co-integration analysis on four different countries in an attempt to establish a causal relationship between asset values and currency rates. According to their research, a rise in the exchange rate causes a rise in stock prices in South Korea. They discovered, however, that stock values in the Philippines are inversely related to exchange rates. In addition to Japan, their studies found that there is no direct correlation between stock prices and exchange rates in Indonesia.

As a result of these contradictory findings, no consensus has been reached on the direction and indications of the connection between stock prices and exchange rates in economics and finance theories. Despite this, the connection between exchange rates and stock prices have been explored using two different models: the commodities market model and the portfolio balance model (Agrawal et al., 2010; Raji et al., 2016; Xie et al., 2020; Salisu, et al., 2021). The 'first model,' developed by Dornbusch and Fisher (1980), emphasizes the relationship between the current account and the exchange rate. They created an exchange rate determination model that takes into account relative pricing, expectations, and asset markets, in addition to the relationship between the exchange rate and the current account. They contend that current account and exchange rate fluctuations are inextricably related. They also assert that a country's currency rate is largely influenced by its trade balance or current account situation. In line with the model, exchange rate variations affect international competitiveness and trade balance, which affects real GDP. As a result, the influence of exchange rate changes on stock prices is determined by the extent of openness of the domestic economy and the extent of the trade deficit. Stock prices and currency rates have a positive link, according to goods market models (Stavarek, 2004).

In addition, the portfolio balance model emphasizes the importance of capital account transactions (Tahir \& Ghani, 2004). In the model, stock prices and currency rates are supposed to have an inverse relationship. Capital flows increase when the value of domestic stocks rises, increasing the demand for the local currency; as well as the exchange rate. A growing stock market fosters local currency appreciation via direct and indirect causes. When prices rise, investors are encouraged to buy local assets by selling international assets and using the proceeds to purchase new domestic stocks. The value of the domestic currency rises as a result of major changes in currency demand and supply. A rise in domestic stock prices, on the other hand, will raise wealth and cause investors to need more cash. As a result, domestic interest rates will rise, attracting international investment and raising foreign investor demand for local currency, resulting in the increased exchange rate and stock price volatility (Stavarek, 2004). Obben et al. (2006) provided empirical evidence that there is a bi-directional causal link between exchange rate and New Zealand stock market prices in the short and long run. Furthermore, Abugri (2008) discovered that the link between exchange rate and stock returns is inverse and statistically significant for both Brazilian and Mexican stock market returns.

However, neither Argentina nor Chile's stock market returns responded greatly to exchange rate changes. Nonetheless, Adam and Tweneboah (2008) find that stock prices and the Ghanaian currency rate have a negative association. In Singapore, however, Maysami et al. (2004) find a positive association between exchange rate and stock market performance. Raji et al. for example were able to accomplish a comparable result (2016). Using monthly data from the stock and foreign exchange markets, they looked at the relationship between the stock and foreign exchange markets in six African countries: Mauritius, Namibia, Nigeria, South Africa, Zambia, and Kenya. The study's findings revealed an inverse linkage between the two financial markets, implying that when stock price index returns rise or fall, so does the exchange rate, resulting in local currency appreciation or depreciation. Muradoglu and Metin (1996) found a direct link 
between stock prices and exchange rates in Turkey. Ozturk (2008), in contrast, discovered that there is no causal association between stock prices and currency rates. Salisu \& Vo's study (2021) discovered a mixed nexus under multiple interest rate regimes. Their purpose was to figure out the way in which exchange rates and stock returns interacted in low and high-interest rate environments, which they classed as advanced industrialized countries and quickly expanding emerging economies, respectively.

Their studies revealed that in the short run, the exchange rate and stock prices in the high-interest rate groups have a substantial negative association. In the long run, however, their data revealed that there is a clear negative connection in a low-interest-rate environment. Furthermore, Yildirtan (2007) discovered no link between exchange rates and stock prices. Demir and Demirhan (2012) established a bi-directional causal linkage between all stock prices and currency rates in their empirical findings. Stock prices can assist predict exchange rates, but not the other way around, according to Xie et al's empirical study (2020). As a result, the statistics cast doubt on the flow-oriented approach to calculating exchange rates. Their findings, however, suggest that there isn't enough evidence to prove unidirectional asymmetric causality between currency rates and stock prices and vice versa. The findings of this study reveal that the literature and debate around the relationship between stock prices and currency rates are inconclusive. The discrepancies in the results could be attributed to the use of different analytical tools and research approaches by different scholars, as well as distinct economic environments.

\section{Data and Methodology}

The study used monthly time series data, spanning the period July 2007 to December 2019; thus, the data were mainly sourced from secondary sources. The stock price data was sourced from the Ghana Stock Exchange, while the data on exchange rates was sourced from the Bank of Ghana. The Johansen and Granger causality test, as well as regression and correlation analysis, was conducted to explore the link between exchange rate and stock prices using the E-views statistical software. The study employed the correlation and regression approach because a review of the literature revealed that the use of econometric models such as the GARCH, EGARCH, and APT has been the most prevalent methodology employed in the analysis of macroeconomic variables in Ghana; multiple regression analysis has been employed rarely in such research in developed economies, and it has been nearly completely missing in emerging markets. Thus, to avoid false regressions, all necessary statistical diagnostics tests such as autocorrelation, multicollinearity, heteroscedasticity, unit roots, and cointegration were performed.

To establish the link between the variables. A model is specified in which stock price is a function of the nominal exchange rate, monetary policy rate or interest rate, money supply, and inflation rate: GSE = $\mathrm{f}$ (NER, MPR, MS, INF), where GSE represents the Ghana Stock Exchange, NER the Nominal Exchange Rate, MPR the Monetary Policy Rate, MS the Money Supply, and INF the Inflation Rate. Monetary Policy Rate (MPR) or Interest rate, money supply, and inflation were included in the model since they were found to be key predictors of stock prices in the research. To determine the data's time series qualities or stationarity attributes, the unit root test was used. The term "stationarity" simply refers to the fact that the mean and covariance of distribution remain the same over a period of time. As a result, stationarity means that the future will be comparable to the past, at least in terms of probability. Nonstationary data regressions, according to Gujurati (2003), give erroneous findings, rendering the $t$ and F statistics useless. In other words, adding a non-stationary variable to a statistical significance test can invalidate it.

As a result, the Augmented Dickey-Fuller (ADF) test was employed to assess if the data was stationary or not by estimating the equation:

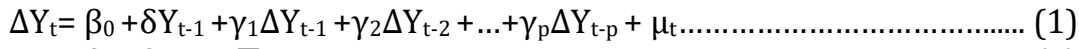

$\Delta \mathrm{Y}_{\mathrm{t}}=\beta_{0}+\delta \mathrm{Y}_{\mathrm{t}-1}+\sum \gamma_{2} \Delta \mathrm{Y}_{\mathrm{t}-2}+\varepsilon_{\mathrm{t}}$

The Augmented Dickey-Fuller (ADF) analysis determines if the variables under consideration have a unit root and therefore must be stated in the first difference form. It expresses the Null hypothesis by claiming that the time series is nonstationary because it lacks a unit root. The Alternative Hypothesis, on the other hand, claims that the time series has a unit root and is thus stationary. Thus;

- $\mathbf{H}_{\mathbf{0}}$ : the series are nonstationary $(=1)$ or lack a unit root.

- $\mathbf{H}_{1}$ : the series are stationary or have only one unit root (1). 
In a situation where the absolute ADF test statistic is less than the crucial value, we reject the Null Hypothesis. On the contrary, in a situation where the absolute ADF test statistic is greater than the crucial value, we accept the Null Hypothesis.

\section{Results and Discussion}

In total, one hundred and thirty-eight observations $(\mathrm{N}=138)$ were used in the investigation. This data set comprises monthly time-series observations from July 2007 to December 2019, the period after the redenomination of Ghana's currency. To determine the basic features of the variables under examination, a variety of descriptive statistical tests were used. Table 1 shows the descriptive characteristics of the variables in the model. According to the findings, the stock price variable had a mean of 3.48258 and a standard deviation of 0.37262 . With a standard deviation of 0.12909 , the average inflation rate was 1.09123 . The mean of the money supply was found to be 4.13342 , with a standard deviation of 0.25106 . The variable interest rate has a mean of 1.188665 and a standard deviation of 0.06168 , with a mean of 1.188665 and a standard deviation of 0.06168 . The standard deviation of the variable nominal exchange rate was 0.14043 , with a mean of 0.20261 . All of the standard deviations showed that the data was widely distributed around its individual means.

Table 1: Group Descriptive Statistics of the Variables

\begin{tabular}{llllll}
\hline Statistics & GSE & INF & MPR & MS & NER \\
\hline Mean & 3.48258 & 1.09123 & 1.18865 & 4.13342 & 0.20261 \\
Median & 3.36325 & 1.07003 & 1.17609 & 4.16226 & 0.17654 \\
Maximum & 4.03706 & 1.31597 & 1.32221 & 4.56635 & 0.50478 \\
Minimum & 2.98515 & 0.92376 & 1.09691 & 3.67009 & -0.03151 \\
Std. Dev. & 0.37262 & 0.12909 & 0.06168 & 0.25106 & 0.14043 \\
Skewness & 0.04212 & 0.27251 & 0.11234 & -0.13255 & 0.42212 \\
Kurtosis & 1.43775 & 1.62085 & 1.92467 & 1.81456 & 2.82075 \\
Jarque-Bera & 9.17891 & 8.24661 & 4.52554 & 5.53329 & 2.79334 \\
Probability & 0.01015 & 0.01619 & 0.10406 & 0.06287 & 0.24741 \\
Sum & 313.432 & 98.2109 & 106.978 & 372.008 & 18.2356 \\
Sum Sq. Dev. & 12.3576 & 1.48321 & 0.33864 & 5.60984 & 1.75525 \\
Observations & 138 & 138 & 138 & 138 & 138 \\
\hline
\end{tabular}

A normal or symmetrical distribution is one in which the distribution's mean, mode, and median values are all the same (i.e., Mean = Mode = Median). Skewness, on the other hand, measures the level of non-symmetry in distribution to ascertain whether the mean is at the center or not. A skewness value of zero denotes a normal distribution (0). A negative number shows a left-skew and, as a result, a negatively skewed distribution, whereas a positive value shows a right-skew and, as a result, a positively skewed distribution. According to the results of the descriptive statistics in Table 1, all of the variables were asymmetrical and thus lop-sided. All of the variables were positively skewed to this effect, except the money supply, which was negatively skewed. In other words, the descriptive statistical test revealed that the data was not normally distributed around its means. As a result, Ghana's stock prices and currency rates are highly vulnerable to periodic volatility and speculation. None of the variables, including GSE, INF, MPR, MS, and NER, were stationary at the levels, although they were all integrated of the first order, or stationary at the first difference, according to the stationarity tests. The ADF results following the first difference are shown in Table 2.

Table 2: ADF, PP and KPSS Unit Root Test for All Variables

\begin{tabular}{llllll}
\hline \multirow{2}{*}{ Test Type } & Deterministic Trend & Test Statistic & \multicolumn{2}{l}{ Critical Values } \\
& & & $\mathbf{1 \%}$ & $\mathbf{5 \%}$ & $\mathbf{1 0 \%}$ \\
\hline \multirow{2}{*}{ ADF } & None & -3.28741 & $-2.59150^{*}$ & $-1.94453^{* *}$ & $-1.61434^{* * *}$ \\
& Intercept & -4.14827 & $-3.50648^{*}$ & $-2.89471^{* *}$ & $-2.58452^{* * *}$ \\
& Intercept and trend & -4.14582 & $-4.06570^{*}$ & $-3.46168^{* *}$ & $-3.15712^{* * *}$ \\
& None & -3.13402 & $-2.59150^{*}$ & $-1.94453^{* *}$ & $-1.61434^{* * *}$ \\
\hline
\end{tabular}




\begin{tabular}{|c|c|c|c|c|c|}
\hline \multicolumn{6}{|c|}{$\begin{array}{c}\text { Journal of Social and Development Sciences (ISSN 2221-1152) } \\
\text { Vol. 12, No. 4, pp. 9-15, December } 2021\end{array}$} \\
\hline PP & $\begin{array}{l}\text { Intercept } \\
\text { Intercept and trend }\end{array}$ & $\begin{array}{l}-4.06252 \\
-4.06340\end{array}$ & $\begin{array}{l}-3.50648^{*} \\
-4.06570\end{array}$ & $\begin{array}{l}-2.89471^{* *} \\
-3.46168^{* *}\end{array}$ & $\begin{array}{l}-2.58452^{* * *} \\
-3.15712^{* * *}\end{array}$ \\
\hline
\end{tabular}

The ADF, PP, and KPSS unit root tests for the first difference of the log of the variables in the regression model are shown in Table 2. According to the findings, the series were significant at the $1 \%, 5 \%$, and $10 \%$ significance levels for all tests since the test statistic value was smaller than the essential threshold in all cases. The findings indicate that the series has reached a state of equilibrium. Table 3 shows the findings of the correlation investigation.

Table 3: Correlation Matrix for All Variables

\begin{tabular}{|c|c|c|c|c|c|c|}
\hline & & LGSE & LINF & LMPR & LMS & LNER \\
\hline \multirow{3}{*}{ LGSE } & Pearson Correlation & 1 & $.673^{* *}$ & $.315^{* *}$ & $-.742^{* *}$ & $-.912^{* *}$ \\
\hline & Sig. (2-tailed) & & .000 & .003 & .000 & .000 \\
\hline & $\mathrm{N}$ & 138 & 138 & 138 & 138 & 138 \\
\hline \multirow{3}{*}{ LINF } & Pearson Correlation & $.673^{* *}$ & 1 & $.837^{* *}$ & $-.258^{*}$ & .004 \\
\hline & Sig. (2-tailed) & .000 & & .000 & .015 & .967 \\
\hline & $\mathrm{N}$ & 138 & 138 & 138 & 138 & 138 \\
\hline \multirow{3}{*}{ LMPR } & Pearson Correlation & $.315^{* *}$ & $.837^{* *}$ & 1 & $.229^{*}$ & $.473^{* *}$ \\
\hline & Sig. (2-tailed) & .003 & .000 & & .032 & .000 \\
\hline & $\mathrm{N}$ & 138 & 138 & 138 & 138 & 138 \\
\hline \multirow{3}{*}{ LMS } & Pearson Correlation & $-.742^{* *}$ & $-.258^{*}$ & $.229^{*}$ & 1 & $.947^{* *}$ \\
\hline & Sig. (2-tailed) & .000 & .016 & .031 & & .000 \\
\hline & $\mathrm{N}$ & 138 & 138 & 138 & 138 & 138 \\
\hline \multirow{3}{*}{ LNER } & Pearson Correlation & $-.0912^{* *}$ & .004 & $.473^{* *}$ & $.947^{* *}$ & 1 \\
\hline & Sig. (2-tailed) & .000 & .966 & .000 & .000 & \\
\hline & $\mathrm{N}$ & 138 & 138 & 138 & 138 & 138 \\
\hline \multicolumn{7}{|c|}{$\begin{array}{l}* * \text {. Correlation is significant at the } 0.01 \text { level (2-tailed). } \\
* \text {. Correlation is significant at the } 0.05 \text { level (2-tailed). }\end{array}$} \\
\hline
\end{tabular}

The findings of a Pearson's Correlation analysis of the exchange rate and stock prices are shown in Table 3. According to the statistics, the exchange rate and stock prices have a moderately negative relationship $(\mathrm{r}=$ $0.912, \mathrm{p} \mathrm{0.01)}$. The null hypothesis should be rejected because the $\mathrm{p}$-value for the correlation between the two variables in the study was less than 0.01 . Furthermore, as shown in table 4 , the results of the multiple regression analysis revealed a negative link between exchange rates and stock prices in Ghana.

Table 4: Ordinary Least Squares Estimates

\begin{tabular}{lclll}
\hline Variable & Coefficient & Std. Error & t-Statistic & Prob. \\
\hline C & 1.802 & 1.706 & 4.316 & 0.000 \\
DLINF & 0.763 & 0.490 & 1.686 & 0.029 \\
DLMPR & -0.892 & 0.974 & 0.924 & 0.038 \\
DLMS & -1.352 & 0.365 & -4.248 & 0.000 \\
DLNER & -1.105 & 0.668 & 1.944 & 0.049 \\
R-squared & 0.832 & & & \\
Adjusted R-squared & 0.783 & & & \\
Durbin-Watson stat & 0.359 & & & \\
F-Statistic & 89.248 & & & \\
\hline
\end{tabular}

The independent variables LINF, LMPR, LMS, and LNER had an R-square value of 0.832 , which means they can explain 83.2 percent of the variation in the dependent variable LGSE. The overall $\mathrm{R}^{2}$ value of the model is high, indicating that it is statistically significant. The adjusted R-squared analyses the explanatory power of varying numbers of predictors in a regression model. It gives the exact and pure percentage of variance in the dependent variable caused by the four (4) independent variables. In this situation, it is 0.783 , which means the independent factors account for 78.3 percent of the variability in the dependent variable. The following is the multiple regression model: DLGSE $=1.802+0.763$ DLINF - 0.892DLMPR - 1.352DLMS - 1.105DLNER; this 
suggests that the linkage between exchange rate and stock prices $(\beta=-1.105, p<0.05)$ is negative or inverse in the Ghanaian context.

\section{Conclusion}

From July 2007 to December 2019; the Pearson's correlation coefficient ( $r=-0.912$, p 0.01) demonstrates a strong negative association between the exchange rate and stock prices in Ghana. This supports the theoretical conclusion that exchange rates and stock prices are inversely connected, ceteris paribus. According to the regression coefficient of -1.104 , a one-unit increase in the exchange rate would result in a 1.105-unit fall in stock prices. The exchange rate and stock prices have a significant negative association $(=-$ $1.105, \mathrm{p} 0.05)$, according to the regression analysis. The study's findings are consistent with those of Enyaah (2011) and Kuwornu and Owusu-Nantwi (2011), who discovered a substantial inverse link between exchange rate and stock market performance. Our findings on the sign and coefficient of the exchange rate variable, on the other hand, contradict those of Adu (2012), who found no meaningful relationship between exchange rate and stock market returns in his research.

Bello (2013) also identified a positive but non-significant relationship between the exchange rate and stock returns. Exchange rate changes and stock market volatility, according to Agrawal, Srivastav, and Srivastava, have a substantial negative link (2010). Mlambo, Maredza, and Sibanda (2013) discovered that currency volatility and stock market volatility had a weak, non-significant relationship. The study concludes that when considering the effects of macroeconomic variables on the stock market, Ghana's monetary policy committee should take into account not only interest rates and money supply but also exchange rates, which have a significant impact on variations in Ghanaian stock prices and the operations of the Ghana Stock Exchange as a whole.

\section{References}

Abugri, B. A. (2008). Empirical relationship between Macroeconomic Volatility and Stock Returns: Evidence from Latin American market. International Review of Financial Analysis, 17(2), 396-410.

Adam, A. M. \& Tweneboah, G. (2008). Macroeconomic Factors and Stock Market Movement: Evidence from Ghana. SSRN Electronic Journal, doi:10.2139/ssrn.1289842.

Adeyeye, O. P., Adewale, O. A. \& Migiro, O. S. (2017). The Nexus between Stock Price and Foreign Exchange Rate: Validating the Portfolio-Balance Model in Nigeria. Afro-Asian J. Finance and Accounting, 7(4).

Adu, G. (2012). Studies on economic growth and inflation, 14.

Aggarwal, R. (1981). Exchange rates and stock prices: a study of the US capital markets floating rates, Akron Business and Economic Review, (12), 7-12.

Agrawal, G., Kumar S. A. \& Srivastava, A. (2010). A Study of Exchange Rates Movement and Stock Market Volatility. International Journal of Business and Management, 5(12).

Alagidede, P., Panagiotidis, T. \& Zhang, X. (2011). Causal relationship between stock prices and exchange rates. The Journal of International Trade \& Economic Development, 20(1), 67-86.

Amarasinghe, A. A. M. D. \& Dharmaratne, D. G. (2014). Dynamic relationship between exchange rate and stock returns: empirical evidence from Colombo Stock Exchange, International Journal of Liberal Arts and Social Science, 2(5), 129-137.

Bahmani-Oskooee, M. \& Saha, S. (2016). Do exchange rate changes have symmetric or asymmetric effects on stock prices? Global Finance Journal, 31, 57-72.

Bello, Z. (2013). The association between exchange rates and stock returns. Investment management and financial innovations, 10(3), 40-45.

Bunheng, K., Sorphasith, X. \& Somchith, S. (2020). Relationship between Exchange Rate and Stock Prices: Empirical Evidence from Cambodia. International Journal of Science and Research, 2319-7064.

Caporale, G. M., Ali, F. M. \& Spagnolo, N. (2015). Exchange rate uncertainty and international portfolio flow: a multivariate GARCH-in-Mean approach, Journal of International Money.

Chkili, W. \& Nguyen, D. K. (2014). Exchange rate movements and stock market return in a regimes witching environment: evidence for BRICS countries, Research in International Business. 
Dornbusch, R. \& Fischer, S. (1980). Exchange Rates and the Current Account. The American Economic Review, 70(5), 960-971.

Enyaah, R. C. (2011). An analysis of the effects of interest rate and exchange rate changes on stock market returns: Empirical evidence of Ghana stock exchange (Doctoral dissertation).

Geske, R. \& Roll, R. (1983). The Monetary and Fiscal Linkage between Stock Returns and Inflation, Journal of Finance, 38, 1-33.

Granger, C. W. J., Haung, B. \& Yang, C. W. (2000). A bivariate causality between stock prices and exchange rates: evidence from recent Asian flu', The Quarterly Review of Economics and Finance, 40(3), 337354.

Gujurati, D. N. (2003). Basic Econometrics, 4th Edition, McGraw-Hill, New York.

Kuwornu, J. K. \& Owusu-Nantwi, V. (2011). Macroeconomic variables and stock market returns: Full information maximum likelihood estimation. Research Journal of Finance and Accounting, 2(4), 49-63.

Maysami, R. C., Howe, L. C. \& Hamzah, M. A. (2004). Relationship between Macroeconomic Variables and Stock Market Indices: Cointegration Evidence from Stock Exchange of Singapore's All-S Sector Indices. Applied Financial Economics, 11, 641-649.

Mlambo, C., Maredza, A. \& Sibanda, K. (2013). Effects of exchange rate volatility on the stock market: A case study of South Africa. Mediterranean Journal of Social Sciences, 4(14), 561.

Muradoglu, G., Metin, K. \& Argac, R. (1996). Is there a long-run relationship between stock returns and Exchange Rates? Journal of International Financial Markets, Institutions and Money, 22(1), 55-86. Journal Pengurusan, 24, 47-77.

Obben, J., Pech, A. \& Shakur, S. (2006). Analysis of the Relationship between the Share Market Performance and Exchange Rates in New Zealand: A Cointegrating VAR Approach. New Zealand Economic Papers, 40(2), 147-180.

Ozturk, B. (2008). The Effects of Macroeconomic Factors on Istanbul Stock Exchange National 100 Index and Its Volatility (1997-2006), Thesis, Istanbul Technical University.

Raji, J. O., Ibrahim, Y. \& Ahmad S. (2016): Stock Price Index and Exchange Rate Nexus in African Markets, International Economic Journal, DOI: 10.1080/10168737.2016.1245354.

Salisu, A. A., Cuñado, J., Isah, K. \& Gupta, R. (2021). Stock markets and exchange rate behavior of the BRICS. Journal of Forecasting. doi:10.1002/for.2795

Salisu A. A. \& Vo X. V. (2021). The behavior of exchange rate and stock returns in high and low-interest-rate environments. International Review of Economics and Finance, 74, 138-149, https://doi.org/10.1016/j.iref.2021.02.008.

Stavarek, D. (2004). Stock Prices and Exchange Rates in the EU and the USA: Evidence of their Mutual Interactions, MPRA Paper No. 7297 [Online] Available at: http://mpra.ub.uni-muenchen.de/7297/.

Tahir, R. \& Ghani, A. A. (2004). Relationship between Exchange Rates and Stock Prices: Empirical Evidence from Bahrain's Financial Markets, EcoMod 2004 International Conference on Policy, Modelling, [Online] Available at: http://www.cepii.fr/anglaisgraph/meetings/2004/3006020704.htm.

Ülkü, N. \& Demirci, E. (2012). Joint dynamics of foreign exchange and stock markets in emerging Europe, Journal of International Financial Markets, Institutions and Money, 22(1), 086. doi:10.1016/j.intfin.2011.07.005

Wickremasinghe, G. (2011). The Sri Lankan stock market and the macroeconomy: an empirical investigation, Studies in Economics and Finance, 28(3), 179-195.

Wong, H. T. (2017). Real exchange rate returns and real stock price returns, International Review of Economics and Finance, 49, 340-352.

Xie Z., Chen S. \& Wu A. (2020). The foreign exchange and stock market nexus: New international evidence. International Review of Economics and Finance 67, 240-266, https://doi.org

Yildirtan, D. C. (2007). Effects of Macroeconomic Variables on Istanbul Stock Exchange Indexes: The Case of Turkish Stock Exchange Market. [Online] Available at: http://www.iuss.info/pdf. 